\title{
Papers
}

Explorations into Children's Literature

\section{Promoting Environmentalism across Media: The Child Figures of The Lorax}

\section{Lichung Yang}

In The Sense of Wonder, first published in July 1956, Rachel Carson describes the awe at the beauty of nature she and her young nephew enjoy along the coast of Maine, USA. She suggests that a child needs an adult with whom to share the wonders of nature. 'If a child is to keep alive his inborn sense of wonder,' writes Carson, 'he needs the companionship of at least one adult who can share it, rediscovering with him the joy, excitement and mystery of the world we live in' (p. 55). She also urges adults to explore nature with feelings and emotions, to use all their senses, and to abandon the impulse to teach or explain. 'For the child, and for the parent seeking to guide him,' she states, 'it is not half so important to know as to feel' (p. 56). Carson is convinced that it is 'more important to pave the way for the child to want to know than to put him on a diet of facts he is not ready to assimilate' (p. 56).

Like Carson, who saw the necessity for adults to guide children to discover the wonder of nature, Dr. Seuss (Theodor Seuss Geisel) created for children a book on environmental issues amidst a wave of popular environmentalism (Lebduska 1994, p. 173). In 1971 Seuss published The Lorax, which addresses the use of natural resources in the age of capitalist and 
industrial expansion. Unlike Carson, however, Seuss turns his attention toward environmental destruction and creates a boy character to usher in the story of 'the Street of the Lifted Lorax' (1971, n.p.). As the story begins, a boy gropes for the old Once-ler who lives at the end of the town, and pays him to find out what the Lorax is and why it has been taken from the town. Instead of sharing with the boy the wonder of nature, the old Once-ler reveals that it is his craziness with 'greed' that has caused 'smogulous smoke,' 'Gluppity-Gluppp,' 'Schloppity Schlopp,' all kinds of pollution, including deforestation of the Truffula trees, and the departure of the forest creatures (Seuss 1971, n.p.). The 1971 book, Dylan Wolfe suggests, 'tempers or challenges outright the ideology of American progressivism, capitalism, and the associated resourcist approach to nature as presented in dominant cultural narratives' (2008, p. 14). It is, Wolfe argues, 'the collision of ecology and the American myth' that produces this 'ecological jeremiad' (p. 14).

The Lorax, which remains a canonical environmental picture book, has not only been used with school children, but has also been adapted into various moving image versions, including the 1972 television special, which frequently aired for American children during the evening prime time; and the 2012 film, four decades later, which premiered on the $108^{\text {th }}$ anniversary of Dr Seuss's birth. Children around the world watch the film or video versions of The Lorax; others may transcode from print to DVD as they visit the Seussville website, read The Lorax and play a Truffula-tree-planting game based on the narrative with touchscreen mobile devices such as smartphones and tablet computers. ${ }^{1}$ The idea that a story can be adapted into different formats is something we have long taken for granted. However, the enduring appeal of Seuss's 1971 book and its multimedia digital formats raises intriguing aesthetic and environmental questions which deserve further consideration. While others interested in The Lorax have provided accounts of the conflicts between the Once-ler and the 
Lorax, and the implications they have for pedagogy or further research in ecocriticism, ${ }^{2}$ I am concerned here with how the child figure or the concept of the child is positioned, addressed, and marketed with regard to environmental issues. What is particularly interesting about the versions of The Lorax, I argue, are the ways in which the child is figured or embodied in different versions, and the extent to which that figuration is connected with environmentalist discourses.

In their influential study Remediation: Understanding New Media, Jay David Bolter and Richard Grusin refer to the representation of one medium in another as remediation, and suggest that this kind of borrowing, which has a long history, comprises 'repurposing' in the contemporary entertainment industry (2000, p. 45). Such borrowing or repurposing can take not merely the content from an earlier medium, but also incorporate and refashion it in a new medium. Bolter and Grusin state that 'media are continually commenting on, reproducing, and replacing each other' (p. 55). Guided but not determined by Bolter and Grusin's concept of remediation, this essay examines the different ways in which Seuss's picture book has been tactically appropriated and refashioned by the 2012 film and the Seussville website. It argues that the 2012 film and the ongoing website respectively repurpose Seuss's 1971 book in order to remake its meanings according to more immediate interests. If Seuss's 1971 book is a wary invitation for children to care for trees, the 2012 film underscores the capacity of (heterosexual) romantic love to awaken and save the world, and the website is designed as an assemblage of virtual spaces featuring Seussian characters, Seuss's books, factual tidbits and relevant products. 
In Seuss's 1971 book, the boy character who searches for the Lorax is unnamed, presented visually in the first page opening through a relatively long shot which seems to dwarf the boy against a vast wasteland. The small village which appears in the background appears to be the place where the boy comes from. Like an editorial cartoon or an advertisement, the verbal text starts with a voice-over narration about the setting and the legendary Lorax by an unseen adult storyteller, who verbalises the boy's wonderings when he adventures alone to the end of the town. The boy is shown as a small figure, looking up at the sign of 'The Street of the Lifted Lorax,' to trigger readers' curiosity and guide them to the old Once-ler's Lerkim. In the second opening, Seuss varies the representation of the boy by having him face readers front on, making eye contact with readers, and demanding their attention. The text here not only articulates the boy's wonderings with a series of questions, but also provides a clue that invites both the boy and readers to keep on searching:

What was the Lorax?

And why was it there?

And why was it lifted and taken somewhere

From the far end of town where the Grickle-grass grows?

The old Once-ler still lives here.

Ask him. He knows. (Seuss 1971, n.p.)

With a turn of the page, the narrative shifts to focus on the Once-ler's reminiscences as he remains in his Lerkim, telling the young boy about how the Lorax was lifted away. The boy may look tiny, occupying little space in the wasteland scene, but his visual perspective and gesture leads readers from the frame story into the story of the Lorax. 
Although the Once-ler takes over the story as the narrator of an embedded narrative, the boy is more than a passive listener but should be acknowledged as an agent who has the capacity for action or for change. The boy may remain mute or silent throughout the book, but he activates the Once-ler's remembering and storytelling. The boy is not shown again until the Once-ler comes to the end of his story in the 1971 book. Significantly, however, listening to the Once-ler's story is a unique opportunity for the boy to have his questions answered, and storytelling is also a second chance for the Once-ler to own his responsibility for the wasteland he has wrought. The boy is portrayed at the end as the agent who helps the Onceler realise the implication of the word of the Lorax. He is not merely the fictive addressee for the old Once-ler, but also stands for those who read the story. He may not be shown in most of the book, nor is any of his verbal interaction with the Once-ler mentioned, but the book ends up by soliciting readers' involvement, having the boy presented once again as a listener to the old Once-ler's story. The fact that the boy stands at the spot from which the Lorax departed also reminds him of the Lorax's words: 'But now,' urges the Once-ler, 'Now that you're here, the word of the Lorax seems perfectly clear. UNLESS someone like you cares a whole awful lot, nothing is going to get better' (Seuss 1971, n.p.).

As an implied listener who pays for the story, the boy is commonly regarded as the one who must receive the Once-ler's story as a message of responsibility. Bob Henderson, Merle Kennedy, and Chuck Chamberlin share the view that the 1971 book concludes by putting the care of the earth, symbolised by the last existing Truffula seed, squarely and precariously in the hands of an individual child. They argue that the Once-ler's anguish over the consequences of his actions 'leads to no personal volition other than to pass on the 
responsibility of righting his wrong to a young boy,' exemplifying a 'standard adult practice' (2004, p. 139). In pointing to the rhetorical gap between narrative problem and narrative solution, Greta Gaard also observes that the ecological crises driven by 'industrial capitalism's profit motive and the "jobs-jobs-jobs" rhetoric are "solved" through a private conversation between the industrialist Once-ler and the environmentalist boy' (2008, p. 16).

However, the unpredictable potentiality of the child is also implicated at the end of Seuss's story, given the intergenerational connection between the adult and the child. Seuss may pose questions of environmentalism to the boy, but the narrative leaves such questions hanging in the picture of the final page. The composite of words and pictures never forecloses the potentiality of the child character in the 1971 book. The boy is, as in Rachel Carson's book, rendered as the future hope of human and natural communities. The Once-ler may provide clear instructions or simple resolutions to the questions raised, but the picture of the final spread does not show what the verbal text delivers-'Plant a new Truffula. Treat it with care. Give it clean water. And feed it fresh air. Grow a Forest. Protect it from axes that hack' (Seuss 1971, n.p.). Instead, it opens up the possibility for the child character to receive the last seed. The last Truffula seed thrown by the Once-ler is visually suspended in the air, showing only the hands of the adult and the child reaching toward each other. Rather than enforcing the conclusion that the boy must receive the seed to comply with the Once-ler's commands, the picture of the suspended seed suggests possibilities for the child to play with the seed. 'With the child,' Amy Sloane states, 'the reader can accept that the child has not caught the seed and that transmission itself remains suspended in the air' (2010, p. 426). 'What comes into play with the child,' suggests Sloane, is 'the experience and decision of orienting, and an experiment in unteachability or primacy of the potential not to, that is, without pedagogy' (p. 427). As an embodiment of hope for the future, the boy is able to play 
with the last of the Truffula seeds in different ways. To take charge of the seed, the boy is not obliged to act according to the command of the Once-ler, but he can do more than what the Once-ler prescribes.

It is Hawley Pratt's 1972 television version of The Lorax that lends further support to the moral obligation that the boy must take on for a potentially alternative future. ${ }^{3}$ In the 25 minute animated special, the boy in white stands in stark contrast to the brownish waste land. The boy, suggests Matthew Teorey, 'does not yet have a rapacious attitude toward nature as promoted by American consumer culture' (2014, p. 333). He is shown not only in the broad context of his environment, but is also depicted in close-ups which foreground his significance. To play down his involvement in consumer culture, the boy does not pay the Once-ler for the story. More significantly, the animation has the boy take the initiative in responding to the Once-ler after his story. While reading the one word the Lorax leaves on the rocks, he cannot help asking: 'What's an unless?' (Pratt 1972). Upon hearing from the Once-ler, he immediately demonstrates a willingness to act, to respond to the call, saying 'A thought about what? About something I ought?' (Pratt 1972). The animation ends with a scene in which the boy catches the last seed and leaves for the place from which he comes while holding the seed in his hands. Instead of a seed of life and hope suspended in mid-air, the 1972 animated version reinforces the moral responsibility the boy assumes in caring for his environment.

Rather than a reproduction of Seuss's story, the movie version of Dr. Seuss' The Lorax (2012) re-visions the print text in a different medium. To lay bare the theatrical display of Seuss's story, the 2012 film presents itself as a staged play built upon the printed text. Before 
the stage curtain opens, the fluffy orange Lorax addresses the audience directly, making it clear that 'there's more to this story than what's on the page' (2012). As the film producer Christopher Meledandri says, the 2012 film both retains Seuss's story and also incorporates what happens before his story (for example, why the young Once-ler comes to the Truffula forests) as well as what happens after his story (for example, why the boy comes to search for the Lorax) (Cornet 2012). Further, the major change in the transfer of the print text to the big screen is that the grim tone of the picture book gives way to a bright, bouncy, candy-colored animation, providing entertainment aimed at the family audience. The computer-generated animated (CGA) film offers a visually rich elaboration of Seuss's hand-drawn world. A cautionary tale with a strong environmental message is transformed into a light-hearted animated musical fantasy which features a child's daring adventures to make his dreams come true.

If he is depicted as an explorer, a listener, and a potential agent in Seuss's book and the 1972 musical animation, the previously unnamed boy is brought to the fore in the 2012 film, where he becomes a main character, Ted Wiggin, whose romantic attraction to a teenage girl drives him to search for the Once-ler in order to find a real tree. By starting with Ted's fascination for the artist Audrey, the animation provides the story with an establishing premise and extends and complements Seuss's story with a teenage romance as the central part of the film narrative. Ted, a middle school boy, is named after Theodor Seuss Geisel, and the teenage girl, named after Audrey Geisel, implicitly refers to Geisel's romance with Audrey. The rousing chorus of 'Thneedville' in the opening sequence also foregrounds a walled city where Ted and his people live, which makes the film Ted's story rather than the Once-ler's reminiscence. The film refashions Seuss's story, making it, in Michel de Certeau's words, 'habitable, like a rented apartment' $(1988$, p. xxi) by filling in the gaps in the print version 
and re-fashioning it in a seemingly utopian future following the deforestation of the trufulla trees.

Despite presenting itself as maintaining Seuss's message of environmentalism, the 2012 film is implicated in the mainstream U.S. cultural imaginary, promoting 'messages of heteronormativity' (Sturgeon 2009, p. 15). In her examination of environmentalism in contemporary American popular culture, Noël Sturgeon argues that mainstream environmentalist narratives are often embedded with problematic assumptions about nature and the natural, such as 'women as Mother Nature,' and 'heterosexuality as natural' (2009, p. 15). Her view of the assumptions of mainstream environmentalist narratives is pertinent to our understanding of the trope of romantic love that establishes itself as the narrative premise of the film. In Ted's quest for a real tree in a world without any living tree, trees are not only transformed into a source of imaginative pleasure but also associated with female characters. In Seuss's book, trees are a source of fabulous wealth. As the Once-ler tells the Lorax, he is preoccupied with 'turning MORE Truffula Trees into Thneeds which everyone, EVERYONE, EVERYONE needs' (Seuss 1971, n.p.). He ends up using up all the Truffula trees, that is, all the resources available. In the 2012 film, however, trees turn into a projection of Audrey's desire for the real, and Grammy Noma's longing for the good old days. Grammy Noma, who serves the role of 'the voice of memory,' remembers real trees and real nature (Belli 2012, n.p.). She knows that real trees have been lost, looks wistfully to the past, and endeavours to help her grandson reclaim it. As an artist, Audrey longs for real trees not as a source of wealth but as an inspiration. Trees become the device that sets up the powerful, almost otherworldly, character of Audrey's imagination as well as Ted's ties to his grandmother. 
Not only are trees and natural wisdom feminised, but Ted is also characterised as a teenage boy motivated by his crush on Audrey to fight against the system epitomised by the greedy behavior of the tyrannical Mayor O'Hare, a small-statured, orientalised male with Bettie Page bangs, whose depiction carries a racialised message about Chinese entrepreneurs. O'Hare is also the head of O'Hare Air, which supplies the highly polluted Thneedville with bottled air. Thneedville, whose inhabitants exist under the silent gaze of the capitalist entrepreneur, is depicted as a walled city, enclosed inside a gated seemingly green community while waste and trash is rampant outside. When real trees disappear, things that are vital to life (such as air, light, and water) are fabricated and valued in commercial terms, and inhabitants naively believe that they are blessed with clean air, pure water and magical trees. In such a flashy concoction, natural and fashion items, people and commodities are fused and confused. The real village, in Baudrillard's words, 'presumed condemned, is sacrificed in advance to its miniaturized, air-conditioned clone (...) which is designed to vanquish death by total simulation' (1994, p. 87). In Thneedville, nature is 'an imaginary referential' taken up by 'the system of political economy and the law of the commodity' (Baudrillard 1988b, p. 121). Here the city is 'absorbed by the hyperreality of the code,' and people's social life is regulated by 'the principle of simulation' (Baudrillard 1988b, p. 120). The inhabitants are turned into consumers, but consumption does not come from objective needs. 'The functionality of goods and individual needs,' in Baudrillard's words, 'only follows on a code of significations and invidious values' (1981, p. 75).

To elevate the status of the boy as a main character who engages in environmental challenges, Ted is first shown as motivated by love, and then attributed with the ability to 
take the responsibility of re-establishing a utopian world once destroyed by the Once-ler. He is depicted as an adventurer in the midst of exuberant exploration, escaping from the garish and claustrophobic city. In order to show Ted performing impossible physical feats to seek out the Once-ler outside the walled city, the digital animation cross-cuts between Thneedville and the wasteland. The Manichean opposition between the Lorax and the Once-ler is reframed and complicated by the confrontation between Ted and Mayor O'Hare. Just as the David and Goliath theme often occurs in Seuss's books, so the conflicts between Ted and Mayor O'Hare make visible the convoluted complexities of bureaucratic capitalist society, reinforcing the dark side of entrepreneurial ventures. On one hand, O'Hare is portrayed as an updated version of the Once-ler who owns his corporation, uses greenwash techniques, and relies on aggressive, saturating advertising campaigns to promote bottled air. On the other hand, as Ted moves inside and outside of Thneedville, the film narrative also moves back and forth between the story of Thneedville and the story of the young Once-ler. As the Once-ler's story is made known to Ted, Thneedville, the seemingly joyful paradise that promises comfort and convenience, is also revealed as a world of lies in which O'Hare uses iron walls to blind people to the wasteland, manufactures a spectacle built on deceit, and monopolises mass media to cloud the truth. Not until the moment when the wall is toppled down do people in Thneedville understand that the world they inhabit is an illusion that serves O'Hare not the community. Like the boy who cried, 'The emperor has no clothes,' Ted lays bare the failings and falsities of Thneedville, telling his people that things are not perfect in Thneedville, and that they are only going to get worse if they do nothing about it. In response to the old Onceler who feels regret, Ted urges his people, 'Unless we change our ways. And we can start by planting this [the last seed]!' (2012). The unnamed boy of Seuss's book is re-mediated and transformed into a generic hero who demonstrates courage and tenacity in overcoming obstacles to the quest for a real tree. In equating Ted's search for a real tree with the pursuit 
of love, the narrative of romantic love also naturalises heterosexual hegemony in the 2012 film.

Despite the fact that the boy Ted acts as an agent for change, speaking for the last seed, and rallying support from his people to get O'Hare dethroned, a degree of ambiguity emerges in the univocal way the Thneedville people celebrate the regenerating power of the tiny seed. The final sequences of the film, including its car chase scenes, highlight Ted's attempts to wake up his people to the broken promises of abundance, creating a fantastic opportunity for building community to solve the problem. Like the ending of the 1971 book, the sequence in which 'small persons' such as a little girl and a delivery man stand up to voice their opinions responds to and embodies the idea of individual and collective action Seuss champions throughout his works. The planting of the last seed is also presented as a symbolic gesture. When the song 'Let it Grow' is used as a plotting device to express the people's views of the tiny seed, the seed suddenly acquires a magic power. However, just as electric trees and bottled air have been naively understood as signs of good life, so the tiny seed is suddenly invested with high expectations. The people in Thneedville seem to be awoken from the nightmare of O'Hare's commodity phantasmagoria, encountering the new alluring object of the last Truffula seed in full consciousness. The vivification of the last seed is almost fetishised, invested with an occult power that makes it much more animated than Thneedville people, who are enchanted by the seed. In a society of the spectacle where primary human needs are replaced by 'a ceaseless manufacture of pseudo-needs' (1994, p. 33), Guy Debord has suggested, 'the social relationship between people is mediated by images' (p. 12), and 'the commodity contemplates itself in a world of its own making' (p. 34). The people of Thneedville seem so mired in 'the spectacle of the society,' and so tied into what the media feeds them that anything new becomes alluring. Getting O'Hare dismissed from office does 
not mean that the system can be overthrown or reversed in an instant. The exchange between O'Hare and the inhabitants of Thneedville encourages an emphasis on the ecological issues that bring people together but simultaneously obscures perceptible differences of power and resources as well as what Baudrillard refers to as the imperceptible 'code of significations and invidious values' (Baudrillard 1981, p. 75) that underlie their problems. Their exchange does not address the complexity of the concept of 'the need' or the way in which ideas about need might result in a basic but evolving form of justification for an alternative Thneedville.

The 2012 film is more than a mere commodity for children or family audience, given its status as a transmedia product, an educational entertainment, an experience, and an environmentalist narrative. However, the advertising efforts Universal Pictures has developed to tie in the movie with a variety of commodities demonstrate that the film contradicts what Seuss's story proclaims in its involvement with capitalist expansion. The movie title, $D r$. Seuss' The Lorax, is unmistakably used as a marketing strategy to gain respectability for the animation, which, as discussed above, centers around Ted's romance and adventure rather than the Once-ler's reminiscence. The iconic figure of The Lorax is also depicted as a fluffy orange creature, deployed by the Studio to endorse and impose an ecological vision for 'more than 70 promotional tie-ins to the movie, with everyone from Mazda to the Environmental Protection Agency to XFinity TV' (Walsh 2012). Ironically, however, the Mazda SUV, a socalled high-environmental-performance vehicle, cannot function without fuel oil, which comes from the petroleum industry that creates havoc on the environment. If Seuss's book and the 1972 musical animation are heavy-handed in their critiques of corporate greed, the advertising campaigns Universal Pictures uses commodifies the 2012 film, transforming The Lorax from a children's book that pulses with a distrust of consumerism into a brand name for extracting maximum profits from it. 
Other than the film version, Seuss's 1971 book, like many other contemporary works, has expanded its narrative through different platforms such as websites, forums, and electronic devices. The popular success of The Lorax has seen its promotion as a teaching resource, providing an excellent example of the complex intersection of environmental texts, consumer texts and pedagogic activities. Carole Scott is right to point out that picture books offer 'a unique opportunity for ... a collaborative relationship between children and adults' $(1999$, p. 101). In Seussville, the official website of Dr. Seuss, the potential for adult-child collaboration is further emphasised and exploited throughout multimodal texts of The Lorax offered through the website. Seussville, as its introduction proclaims, is the place for 'children of all ages' to explore Dr. Seuss's books and the classic characters who dwell in his world. The navigation bar placed at the top of the Seussville homepage includes not merely book descriptions, author's introduction, video, Seussian characters, games and activities but also web pages targeting educators and parents.

The virtual world of Seussville is one of Random House's websites featuring children's books. Random House Children's Books, which has been a publishing partner with Dr. Seuss Enterprises since the huge success of The Cat in the Hat in 1957, is part of the international corporate entity that publishes Dr. Seuss' books. Seussville is designed as a branded environment where visual images of Seuss's icon characters and audio versions of their stories are provided. Here the book characters have been taken away from the pages of the books, and remediated into what Diane Carver Sekeres calls, 'market children' (2009, p. 406). As Sekeres suggests, a market child is an imaginary character who lives not only through the pages of the book but also represents a brand to live on video, film, and websites. 
A market child occupies the 'playspace' which the reader/viewer constructs 'through reading, from books to toys to online games' (p. 406). Seussville is characterised by a juxtaposition of Seussian places, including Whoville, Mulberry Street, McElligot's Pool, and the Jungle of Noo where a plethora of Seussian icon characters dwell. Each character image is a reification of some aspect of the Seussian world as well as a hypermediation of the print text. In the case of Seuss's 1971 book, the icon of the Lorax is selected as one of the market children to inhabit Seussville. The Lorax page is a constellation of small sites or hyperlinks, including a read-aloud of an excerpt from the book featuring the Lorax character, a two-minute film clip of 1972 animation briefing on part of the storyline, and activities and games for young readers.

In addition to hyperlinks, earth-friendly tips from the Lorax and the Lorax Project are also offered. As its website proclaims, The Lorax Project was launched on Earth Day 2008 to connect the message of The Lorax to real life conservation initiatives. The Lorax character is appropriated to connect Seuss's book with real-world populations of plants and animals. Besides common games and activities, the Lorax Project offers information tidbits as well as snapshots of forests at risk and endangered animals worldwide. These endangered species are termed 'friends of The Lorax,' who are described as the animals the Lorax meets when he travels around the world. The forest areas at risk are compared to the Truffula trees that demand protection from people. When factual information is offered to promote environmental learning, photographic images of animals and forests and simulated surround sound are also provided in order to create a lifelike experience. As can be seen, the Lorax is much more than a book character or any other particular product that carries the name, and is almost the equivalent to what one would call an environmentalist who believes trees and all living creatures should not be harmed. This remediation of the Lorax into a conduit to the far- 
off places and endangered species in virtual space offers a learning option to keep readers reading beyond the print book.

However, the Lorax character is not a stand-alone environmentalist, nor is Seussville designed solely as a source of information about Dr. Seuss and his books. The Seussville website is also designed to sell products through a complex network of multimodal texts. With its origins in book space, where connections between books, educational materials, video films, games have developed, a kind of 'intertextual commodity' serves to make a commercial space that promotes linked materials such as the books and tie-ins, in an effort to sell more products or increase consumer loyalty (Marshall 2002, p. 72). This new intertextual commodity provides an ambience where products are deliberately linked to educational games and learning activities on the premise of the brand. Accordingly, when browsing the intertextualised Lorax, readers are from time to time shown an image of the printed book, and reminded to find out more about The Lorax and Dr. Seuss. If they click on the image of the book cover, readers will see a brief book description featuring not merely the book itself but also emphasising that it is a book with movie tie-ins: 'With the release of the blockbuster film version, the Lorax and his classic tale have educated a new generation of young readers not only about the importance of seeing the beauty in the world around us but also about our responsibility to protect it. ${ }^{4}$ Not only is environmentalism incidentally promoted, but the intertextual connection between the printed book, the film and the website is explicitly intensified and displayed in Seussville. As Daniel Hade and Jacqueline Edmonson have suggested, the 'effect of licensing, synergy, and vertical integration on children's books is that the book and each spin-off piece of merchandise and each retelling across another medium become a promotion for every other product based upon that story' (p. 139). 
In his study of the society of consumption, Baudrillard states that 'few objects are offered alone, without a context of objects to speak for them' (1988a, p. 31). He adds, 'the object is no longer referred to in relation to a specific utility, but as a collection of objects in their total meaning' (1988a, p. 31). In the case of The Lorax, the recently remediated versions, including the 2012 film and its Seussville website, may maintain Seuss's message of environmentalism, may evoke nostalgia in the early generations who used to read Dr. Seuss in their childhood and elicit familiarity-based recognition in the young generations who are now reading or have heard about Dr. Seuss, and may take advantage of contemporary society's fascination with new media. But the peritextual materials mentioned above definitely inform the narratives as they are reframed; the cross-referencing between the environmentalist narratives and webs of commodities initiated by the corporations across the platforms is now a fundamental aspect of product marketing in a capitalist society.

Dr. Seuss's 1971 book and the 1972 TV animation resonate with Rachel Carson's message, and aim to suggest the unpredictable potentialities of the child and the moral responsibility he must take for the future. Four decades later, the remediated versions of The Lorax also retain and extend Seuss's story to various degrees. The Lorax has become a 'branded' book, and reading it is only a part of the creation of meaning. A juxtaposed reading of the different remediations of The Lorax implies that the printed book is no longer the only or necessarily the most important space in which we locate or read Dr. Seuss. The four media - the book, the TV special, the film, and the website - concur that the environment is in need of care and protection by humans, a viewpoint held by environmentalists for decades. What underlies these texts is the common assumption that the child is an agent for the future. All of them 
promote their belief in the next generation of children as the stewards of nature, and illustrate this belief.

As shown above, however, the latest film version and the Seussville website change the focus of their remediation by refashioning or refiguring the child character in Seuss's book. The original Lorax book is arguably environmentalist, but it has been co-opted by the many consumer products whereby it is refashioned and remediated. In the 2012 film, the environmentalist message Seuss conveyed in 1971 is transformed into an entertaining musical fantasy, and the Lorax character is appropriated into a market child to promote environmental learning. If Dr. Seuss's The Lorax, a parable about industrialism, consumerism, and pollution which run amok, ushers in the message of individual responsibility for our environment, the 2012 animation circumnavigates the doom and gloom of a bleak tale by granting closure to it through romantic love and youth's adventure. The CGI musical animation keeps Seuss's message at the heart of the story and delivers a delightful film which engages with (heterosexual) young love as its premise to engage the family audience. The Lorax webpage of Seussville also presents itself an intertextual commodity, which urges children to be consumers as well as readers. The webpage not merely promotes environmental messages but also urges readers to purchase the products of the brand.

Diane Carver Sekeres notes that 'as the market child is storied through virtual, scripted, printed, molded, and written conceptualisations, the possibility of knowing characters from media other than books is a significant and influential change in a child's literate imagining' (2009, p. 412). A reading of the different remediations of The Lorax prompts us to rethink the 
multiple positions that real children have to take in order to interrogate the dialogue or symbiosis between print and electronic texts, more specifically between the formal aspects of the medium and the generated messages. More significantly, what is at stake nowadays is no longer a clash between environmentalism and capitalism, but an inevitable entanglement of environmentalism and capitalism. The other big question that remediation raises is, how can a book that promotes an environmental message be made relevant and engaging for all children and less dominated by a corporate or capitalist culture?

\section{Notes}

1. 'Over 50 Dr. Seuss Apps are available on the App store, Google Play, Amazon and Nook,' says Oceanhouse Media, Inc., a publisher of iOS and Android apps. See its website: http://www.oceanhousemedia.com/apps/drseuss/. For the game 'Lorax Garden' see the website of iTunes App Store: https://itunes.apple.com/us/app/loraxgarden/id366510234?mt=8. At present, the Lorax App is designed only for iPhone and iPad. Those who cannot afford an iphone or an ipad may not have the opportunity to use the Apps.

2. In the years since the book's publication, the Lorax has become not only an icon of environmental conservation but also 'a target of the logging industry' in the United States (Nel 2004, pp,173-178). Matthew Teorey's essay suggests how the original Lorax book belongs to its early-1970s context, and Michelle Abate's work (2010) on the Truax shows how 1980s conservatives attacked Seuss's work. Additionally, Ian S. Marshall's essay (1996) 'The Lorax and the Ecopolice' has evoked responses from Suzanne Ross (1996) and Bob Henderson, Merle Kennedy, and Chuck Chamberlin (2004) as to environmental rhetoric and 
pedagogy in The Lorax. Nathalie op de Beeck (2005) draws attention to the resources we use when producing and consuming goods like picture books. Greta Gaard also provides an overview of the recent ecocritical analyses of The Lorax (2008, pp. 16-17).

3. Seuss scripted and produced an animated musical of The Lorax which won him an award at the International Animated Cartoon Festival. See Morgan \& Morgan 1995, pp. 106-116, 118-132, 223.

4. See the website http://www.seussville.com/books/book_detail.php?isbn=9780394823379. Other books by Seuss are also displayed and hyperlinked as 'related items' besides the book cover and a book description of The Lorax. The eponymous Cat in the Hat, the iconic image of the National Educational Association's annual Read Across America campaign, is reading in place, suggesting a potential connection between the promoted items and a nationwide reading event.

\section{Acknowledgements}

I would like to express my deep gratitude to Clare Bradford, Kerry Mallan, and the two anonymous reviewers for their constructive comments and valuable suggestions, which have helped to improve this essay. It has also been made possible by support from the Ministry of Science and Technology, Taiwan (NSC 102-2410-H-845-009-MY2). An early version of the essay was presented at the Conference on Shifting Paradigms in Children's Literature at Shoochow University, Taiwan, November 8, 2014. 


\section{References}

Abate, Michelle Ann (2010) Raising Your Kids Right: Children's Literature and American Political Conservatism. New Brunswick, NJ: Rutgers University Press.

Baudrillard, Jean (1981) For a Critique of the Political Economy of the Sign, trans. Charles Levin. St. Louis: Telos.

--- (1988a) 'Consumer Society', in Mark Poster (ed) Jean Baudrillard: Selected Writings. Cambridge: Stanford University Press, pp. 29-56.

(1988b) ‘Symbolic Exchange and Death', in Mark Poster (ed) Jean Baudrillard: Selected Writings. Cambridge: Stanford University Press, pp. 119-148.

— (1994) The Illusion of the End, trans. Chris Turner. Stanford, CA: Stanford University Press.

Belli, Brita (2012) 'Saving the Truffula Trees: An Interview with The Lorax Director Chris Renaud'. E: The Environmental Magazine (Mar): n. p., retrieved from: http://www.emagazine.com/magazine/saving-the-truffula-trees [Accessed August 26, 2015]

Bolter, Jay David and Richard Grusin (2000) Remediation: Understanding New Media. Cambridge: The MIT Press.

Carson, Rachel (1998/1956) The Sense of Wonder. New York: HarperCollins. 
Cornet, Roth (2012) 'Dr. Seuss’ The Lorax’ Edit Bay Visit \& New Images'. January 30, retrieved from: http://screenrant.com/dr-seuss-lorax-edit-bay-visit-images-rothc-

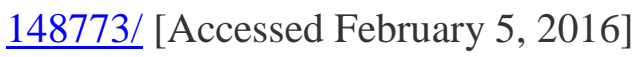

Debord, Guy (1994) The Society of the Spectacle, trans. Donald Nicholson-Smith. New York: Zone Books.

de Certeau, Michel (1988) The Practice of Everyday Life, trans. Steven Rendall. Berkeley: University of California Press.

Dr. Seuss (Theodor Seuss Geisel) (1971) The Lorax. New York: Random House.

Gaard, Greta (2008) 'Toward an Ecopedagogy of Children's Environmental Literature', Green Theory \& Praxis: The Journal of Ecopedagogy 4 (2): 11-24.

Hade, Daniel and Jacqueline Edmondson (2003) 'Children's Book Publishing in NeoLiberal Times', Language Arts 81: 135-143.

Henderson, Ben, Merle Kennedy, and Chuck Chamberlin (2004) 'Playing Seriously with Dr. Seuss: A Pedagogical Response to The Lorax', in S. I. Dobrin and K. B. Kidd (eds) Wild Things: Children's Culture and Ecocriticism. Detroit: Wayne State University Press, pp. 128-148.

Lebduska, Lisa (1994) 'Rethinking Human Need: Seuss's The Lorax', Children's Literature Association Quarterly 19 (4): 170-176.

Marshall, Ian S. (1996) 'The Lorax and the Ecopolice', ISLE: Interdisciplinary Studies in Literature \& Environment 2 (2): 85-92. 
Marshall, P. David (2002) 'The New Intertextual Commodity', in D. Harries (ed.) The New Media Book. London: British Film Institute, pp. 69-81.

Morgan, Judith, and Morgan, Neil (1995) Dr. Seuss and Mr. Geisel. New York: Random House.

Nel, Philip (2004) Dr. Seuss: American Icon. New York and London: Continuum Publishing.

op de Beeck, Nathalie (2005) 'Speaking for the Trees: Environmental Ethics in the Rhetoric and Production of Picture Books', Children's Literature Association Quarterly 30 (3): 265-287.

Pratt, Hawley (1972) dir. The Lorax. Burbank, CA: DePatie-Freleng Enterprises.

Renaud, Chris (2012) dir. Dr. Seuss' The Lorax. Universal City, CA: Universal Studios Home.

Ross, Suzanne (1996) 'Response to “The Lorax and the Ecopolice” by Ian Marshall', ISLE: Interdisciplinary Studies in Literature and Environment 2 (2): 99-104.

Scott, Carole (1999) 'Dual Audience in Picture Books', in Sandra Beckett (ed) Transcending Boundaries: Writing for a Dual Audience of Children and Adults. New York: Garland, pp. 99-110.

Sekeres, Diane Carver (2009) 'The Market Child and Branded Fiction: A Synergism of Children's Literature, Consumer Culture, and New Literacies', Reading Research Quarterly 44 (4): 399-414.

Sloane, Amy (2010) 'Reading The Lorax, Orienting in Potentiality', Environmental Education Research 16 (3-4): 415-428.

Sturgeon, Noël (2009) Environmentalism in Popular Culture: Gender, Race, Sexuality, and the Politics of the Natural. Tucson: The University of Arizona Press. 
Teorey, Matthew (2014) ‘The Lorax and Wallace Stegner: Inspiring Children’s Environmental Activism', Children's Literature in Education 45 (4): 324-339.

The Lorax at Seussville (2015), retrieved from http://www.seussville.com/books/book_detail.php?isbn=9780394823379 [Accessed August 26, 2015]

The Lorax Project (2015), retrieved from http://www.seussville.com/loraxproject/ [Accessed August 26, 2015]

Walsh, Bryan (2012) 'Why The Lorax Shouldn't Be Selling SUVs', Time Tuesday, Mar. 6. Retrieved from http://content.time.com/time/health/article/0,8599,2108368,00.html [Accessed February 2, 2016]

Wolfe, Dylan (2008) 'The Ecological Jeremiad, the American Myth, and the Vivid Force of Color in Dr. Seuss's The Lorax', Environmental Communication 2 (1): 3-24.

\section{Biographical Note}

Lichung Yang is currently an associate professor in the Department of English Instruction at University of Taipei in Taiwan where she teaches children's literature in the undergraduate and graduate programs. Her chief research interests include picture book studies, and the relation between picture book reading and the practice of literacy in the EFL context. 